Board of Governors of the Federal Reserve System

International Finance Discussion Papers

Number 624

September 1998

"BIG BANG" DEREGULATION AND JAPANESE CORPORATE GOVERNANCE: A SURVEY OF THE ISSUES

Michael S. Gibson

NOTE: International Finance Discussion Papers are preliminary materials circulated to stimulate discussion and critical comment. References to International Finance Discussion Papers (other than an acknowledgment that the writer has had access to unpublished material) should be cleared with the author or authors. Recent IFDPs are available on the Web at www.federalreserve.gov. 


\title{
"BIG BANG" DEREGULATION AND JAPANESE CORPORATE GOVERNANCE: A SURVEY OF THE ISSUES
}

\author{
Michael S. Gibson ${ }^{*}$
}

\begin{abstract}
The "Big Bang" deregulation of Japanese financial markets focuses on financial modernization. I argue that financial modernization is of secondary importance for improving the performance of the Japanese economy. A key long-term issue facing Japan is to maintain its high level of per capita income in the face of an aging population and slower productivity growth. To achieve this, it is important to increase the return earned on Japan's large stock of wealth. I argue the low return on wealth reflects characteristics of the Japanese corporate governance system. The proper focus of the "Big Bang" should be on measures to strengthen corporate governance.

I identify three characteristics of the Japanese corporate governance system that lead Japanese managers to produce low returns for shareholders. First, insider stakeholders dominate corporate governance. Second, institutional investors are weak. Third, there is no market for corporate control. For each characteristic, I describe potential changes which would strengthen Japanese corporate governance. For each potential corporate governance change, I review empirical evidence on its effectiveness, its current status in Japan, and how it is addressed, if at all, in the "Big Bang." I conclude that the progress of the "Big Bang" reforms to corporate governance has been limited.
\end{abstract}

Keywords: executive compensation, stock options, independent directors, share buybacks, institutional investors, market for corporate control, minority shareholders

*Email: michael.s.gibson@ frb.gov. I thank colleagues at the Federal Reserve Board and participants in the 1998 NBER Japan Project Meeting in Cambridge, Mass. for helpful comments on a previous draft. Remaining errors are the responsibility of the author. The author is a staff economist in the Division of International Finance. The views in this paper are solely the responsibility of the author and should not be interpreted as reflecting the views of the Board of Governors of the Federal Reserve System or of any other person associated with the Federal Reserve System. 


\section{Introduction}

In November 1996, Japanese Prime Minister Hashimoto announced a "Big Bang" deregulation of Japanese financial markets. The "Big Bang" began in April 1998 when all remaining restrictions on foreign exchange transactions were removed. It is scheduled to continue through 2001. A wide range of financial deregulation measures will fall under the umbrella of the "Big Bang." Table 1 reproduces a table from the Japanese financial press listing the "Big Bang" deregulation agenda. The list is dominated by measures to remove restrictions on how banks and securities firms do business and allow cross-entry of banks, securities firms, and insurers into each others' businesses.

In this paper, I argue that such "financial modernization" measures are of secondary importance for improving the performance of the Japanese economy. A more important problem facing the Japanese economy is the low return earned on Japanese wealth. Raising the return on Japan's huge stock of wealth will be key for Japan to maintain a high level of per capita income in light of two facts. First, Japan's population is aging rapidly, which will slow Japan's rate of labor force growth. Second, Japan's industrial firms are on the frontier of technology, so Japan's rapid productivity growth of the 1960 s and 1970 s is unlikely to be repeated.

I argue that the low return on Japan's wealth reflects characteristics of the Japanese corporate governance system. Although the Japanese corporate governance system played a key role in Japan's outstanding economic performance of the 1960s and 1970s, times have changed and the Japanese corporate governance system has not. I argue that the proper focus of the "Big Bang" deregulation should be on measures to strengthen corporate governance. I suggest specific 
changes, some of which have already been begun to occur, that might lead to improved corporate governance in Japan. ${ }^{1}$

One well-known feature of the Japanese economy is the dominant role of industrial groups known as keiretsu. The majority of large Japanese firms belong to a keiretsu. Research has shown the corporate governance structures of keiretsu and non-keiretsu firms to be remarkably different. ${ }^{2}$ In addition, research has found that keiretsu firms have lower average profitability than non-keiretsu firms. ${ }^{3}$ This difference in performance should not be blamed entirely on corporate governance, since there are many other ways in which keiretsu firms and non-keiretsu firms differ. While some of the corporate governance mechanisms I discuss relate mainly to keiretsu firms, others apply throughout the Japanese economy.

In the next section of the paper, I document the low returns on Japanese wealth over the past two decades and discuss possible causes linked to corporate governance. Section 3 discusses three characteristics of the Japanese corporate governance system that reduce the pressure on Japanese firms to maximize returns for shareholders. I stress the point that the Japanese corporate governance system has not prevented Japan from producing world-class firms in many industries; however, it has not been effective at producing high returns for Japanese wealthholders in recent years. For each characteristic discussed in Section 3, Section 4 goes into detail on possible changes to Japanese corporate governance, some of which have already

${ }^{1}$ A minority of authors discussing the "Big Bang" have also argued for the importance of corporate governance, e.g., Fukao (1998) and "Japan's Ray of Hope," Financial Times, May 6, 1998.

${ }^{2}$ See, for example, Prowse (1992), and Hoshi, Kashyap, and Scharfstein (1990, 1991).

${ }^{3}$ Nakatani (1984). 
occurred as part of the "Big Bang." For each corporate governance mechanism, I review empirical evidence on its effectiveness, its current status in Japan, and how it is addressed, if at all, in the "Big Bang." Section 5 concludes.

\section{Japan's low return on equity: evidence and causes}

Japanese households have had a high saving rate for a long time. As a result, they have accumulated a large stock of wealth. As is true of most countries, Japan's wealth has been invested disproportionately in domestic assets. This stock of wealth has not produced high returns for Japanese households. In particular, equity investments have not produced as high returns in Japan as in the United States, especially in recent years. ${ }^{4}$

\subsection{Evidence on return on equity in Japan}

Return on equity in Japanese firms, whether measured stock market returns or using accounting returns, has been low compared with the return earned by U.S. firms. Both stock market and accounting returns are imperfect measures of the true return on equity, but they tell the same story. Beginning with 1980, when foreign investment by Japanese investors was liberalized, the continuously compounded annual return on Japanese stocks has been 7.3 percent, compared to 16.3 percent in the U.S. (see Table 2, Panel A). The difference is exaggerated but not caused by the steep increases in U.S. stock prices in recent years. Ending the sample period in 1994, returns were 9.8 percent in Japan and 13.5 percent in the U.S. Measuring returns as the excess return of the stock market over a domestic risk-free interest rate does not change the

${ }^{4}$ This fact is acknowledged with different emphasis in the literature that argues Japanese companies face a lower cost of equity capital than U.S. companies. See, for example, McCauley and Zimmer (1989). 
conclusion that Japanese corporations have produced lower returns for shareholders, though it does narrow the gap (see Table 2, Panel B). Accounting returns on equity are shown in Figure 1. Again, returns of Japanese firms fall short of those of U.S. firms. ${ }^{5}$

Shareholders in Japanese firms have an additional reason to be concerned. Not only is the mean return on Japanese equities low, but returns have been especially low in recent years. The slump in accounting returns is evident in Figure 1. Figure 2 shows annual stock market returns for Japan. It is clear that the returns earned by Japanese shareholders have been on a downward trend. I argue below that this trend is neither an artifact of noisy data nor purely a consequence of the Japanese recession. Rather, it reflects real economic trends, including characteristics of the Japanese corporate governance system. The next subsection discusses three such characteristics.

\subsection{Causes of Japan's falling return on equity}

\subsubsection{Japanese firms make poor use of free cash flow}

According to Kester (1991), Japanese firms make poor use of cash flow in excess of what is required to maintain a firm's ongoing operations. In other words, the success of Japanese firms has made the lack of focus on profit by Japanese managers more costly. By virtue of their success, Japanese firms have reduced their need for outside funding and reduced the ability of the

${ }^{5}$ French and Poterba (1991) examined differences in accounting standards that cause earnings of Japanese firms to be understated relative to those of U.S. firms. They concluded that differences in accounting could not explain all of the difference in the average price-earnings ratio between Japan and the U.S. up to 1990. It is thus unlikely that accounting differences could explain all of the difference in the average accounting rate of return between Japan and the U.S.

Moreover, accounting differences lead book value to be understated at Japanese firms relative to U.S. firms, which would tend to inflate Japanese firms' accounting rate of return relative to that of U.S. firms. The leading example is the land and equities that Japanese companies carry on their books at acquisition cost. For many firms, acquisition costs date from the 1940s or 1950s. 
providers of external funds to monitor managers. According to Kester (1991), "the managerial discretion afforded by excess cash has given rise to the expression of latent self-interests that were successfully contained during Japan's high growth period." This explanation is consistent with the declining returns on Japanese equity shown in Figure 1 and Figure 2.

\subsubsection{Bank monitoring is increasingly ineffective}

Japanese banks own substantial equity in non-financial firms. One of the characteristics of the Japanese corporate governance system that has been identified as an advantage is the ability of banks to be both lenders and shareholders. In support of this proposition, Prowse (1990) found evidence that the agency problem between a firm's shareholders and debtholders was diminished in Japan, reducing the distortionary effect of debtor-shareholder conflicts on a firm's capital structure decision.

However, this characteristic seems to be vanishing. With the deregulation of Japanese financial markets in recent years, alternatives to bank debt have become available to large Japanese firms. Many large firms have replaced bank loans with direct borrowing from capital markets (bonds and commercial paper). Also, Japanese banks are under increasing pressure to restructure and improve performance (Fukao 1998). As a result, banks are reconsidering the wisdom of holding large equity investments. As non-financial firms gradually sell their bank shares as their reliance on bank loans falls, banks have less of an incentive to hold shares of nonfinancial firms for the purpose of cementing a customer relationship. As a result, the ability of the Japanese corporate governance system to use bank monitoring to reduce the agency costs of debt have fallen and can be expected to continue falling. 


\subsubsection{Lost profits due to deregulation have not been replaced}

Finally, deregulation of product markets has reduced the rents earned by Japanese companies. For example, interest rate deregulation has raised the cost of funds of Japanese banks, and some of the increase has been passed along to borrowing firms (as was some of the rent in the regulated environment). In some firms, the resulting decline in profits has not been replaced, leading to a lower return on equity.

\section{Corporate Governance and the Problem of Low Returns}

In this section, I discuss three reasons why Japanese firms produce low returns for shareholders. First, the Japanese corporate governance system gives primacy to insider stakeholders, not outside shareholders. Second, institutional investors, a class of shareholders that has tried to influence managers of U.S. firms to focus on shareholder returns, are weak in Japan. Third, there is no market for corporate control in Japan.

\subsection{Managers serve stakeholders, not outside shareholders}

Equity ownership in Japan is dominated by insider stakeholders, a group that includes lenders, customers, suppliers who also have financial or product market relationships with the firm. According to data presented in Fukao (1998), insider stakeholders held 38 percent of the shares of large Japanese firms in 1996. In the Japanese corporate governance system, these insider stakeholders monitor the firm's managers, and outside shareholders have little or no role in corporate governance. Insider stakeholders profit from the return on their equity investment and from the return on their other relationships with the firm. A focus purely on profit maximization-which could include seeking out lower interest rates on bank loans, lower prices 
from suppliers, or higher prices from customers-could put managers at odds with insider stakeholders. Since it is these stakeholders who monitor managers, it is logical for managers not to focus exclusively on maximizing profit. Given the poor performance of Japanese financial institutions in recent years, it is interesting that the data on insider shareholders cited in Fukao (1998) show that insider stakeholders hold 50 percent of the shares of financial institutions, compared with only 25 percent of non-financial firms. ${ }^{6}$

In the Japanese corporate governance system, outside shareholders can have only limited influence on Japanese managers. Outside shareholders are often in the minority. Also, in the past, holders of large minority stakes in Japanese companies have often been accused of "greenmail." Japanese "greenmailers" have abused the statutory rights accorded to large minority shareholders, such as the right to inspect the company books, by threatening to exercise those rights in a way that would embarrass a firm's managers? As a result, Japanese firms have become wary of large minority shareholders and the rights of such shareholders have been curtailed, de facto if not de jure.

\subsection{Institutional investors are weak in Japan}

Institutional investors, such as pension funds, mutual funds, and insurance companies, pool the assets of many households. They can more readily achieve the large shareholdings necessary to overcome the bias to inaction caused by free-rider problems. However, in Japan institutional investors are small. Institutional investors in Japan control just 16 percent of

${ }^{6}$ Hanazaki and Horiuchi (1998) argue that ineffective corporate governance has contributed to the depth and duration of the current Japanese banking crisis.

${ }^{7}$ See Okumura (1989). 
household assets, compared with 33 percent in the U.S. (see Table 4). There are several reasons why. Japanese corporate pensions are typically of the defined benefit form and many pension plans are underfunded. In contrast, U.S. pensions are increasingly of the defined contribution type, which are necessarily funded in advance. Taxation of pensions favors defined benefit-type plans over defined contribution-type plans in Japan (Morinaga and Fukao 1997). Restrictions on pension fund investments (lifted in 1997) made it hard for pension funds to achieve high returns. Mutual funds in Japan are much less important than in the U.S., primarily because the tax treatment of mutual fund investments is less favorable to investors than the tax treatment of direct purchase of equities. Largely because of the unfavorable tax treatment, Japanese mutual funds have underperformed their benchmarks by large amounts (Cai, Chan and Yamada 1997). Japanese institutional investors do not have a history of exerting pressure on companies to increase shareholder returns. ${ }^{8}$ The largest institutional investors in Japan, life insurance companies, have typically adopted a passive role in corporate governance. Often life insurers act as inside stakeholders-using their shareholdings as a way to retain the insurance business of a firm and its employees-rather than pressuring managers to maximize shareholder wealth. Corporate pension funds, too, are often managed in the interest of the funding corporation rather than the interest of the pension beneficiaries. The small size of institutional investors and their limited appetite for shareholder-oriented governance pressure have contributed to Japan's problem of low return on invested wealth.

\footnotetext{
${ }^{8}$ Of course, U.S. institutional investors did not have such a history twenty years ago.
} 


\subsection{There is no market for corporate control in Japan}

Individual shareholders face a free-rider problem when considering trying to force managers to pay more attention to shareholder returns. The benefit of improved corporate performance accrues to all shareholders, even those who do not exert any effort to force change. The free-rider problem implies that individual shareholders will only take action to force managers to focus on shareholder returns when the cost of the action is small. Many governance mechanisms, such as electing candidates to the board of directors or sponsoring resolutions at the shareholders' annual meeting, are so costly that they are rarely pursued by individual shareholders. The primary way individual shareholders contribute to effective corporate governance in the U.S. is by tendering their shares to the highest bidder when a firm is the subject of a hostile takeover.

Hostile takeovers have been rare in Japan. Data for 1994-96 show that the average annual value of mergers was 0.4 percent in Japan, compared with 6.1 percent of GDP in the U.S. ${ }^{9}$ To a greater extent than in the U.S., Japanese firms depend on long-term relationships with suppliers and customers. These relationships are not based on the performance of specific contractual obligations. Rather, they depend on an unwritten understanding that both parties have made investments that are tailored to that relationship and both parties deserve to earn a fair return on those investments. It is unlikely that this network of relationships could have grown and prospered in an environment where hostile takeovers were common.

${ }^{9}$ Securities Data Publishing, The Merger Yearbook: U.S./International Edition 1997, p. xxii. Of course, only a fraction of this merger activity is motivated by corporate control reasons. The figure for Japan would be 0.1 percent of GDP if the merger of Bank of Tokyo and Mitsubishi Bank were excluded. 
Moreover, equity ownership in Japan is dominated by stakeholders, a practice often described as "cross-shareholding." If a majority of the target firm's shares are cross-held, a potential acquirer must convince at least some stakeholders to sell. Only if the acquirer can convince a firm's stakeholders that the overall return on their relationships with the target firm will be higher if the firm is taken over would the stakeholders agree to sell. ${ }^{10}$ In general, a takeover is made more difficult (or expensive) when the target's shares are not widely held.

\subsection{The Japanese corporate governance system is not dysfunctional}

It would be wrong to say that the Japanese corporate governance system is dysfunctional. Japan's past outstanding economic performance proves that Japan's economic structure, including the Japanese corporate governance system, has worked well. Most researchers agree that it does an excellent job of facilitating specific investments and information sharing among employees, suppliers, and customers. ${ }^{11}$ However, most researchers also agree that it does not lead managers to seek to maximize shareholder returns.

Researchers have documented the success of the Japanese corporate governance system in imposing checks on corporate managers. Berglof and Perotti (1994) show that the keiretsu system of corporate groups, in theory, can prevent managers from shirking. Table 3 presents data from Kaplan and Minton (1994) showing that the frequency of external monitoring by a large shareholder, in the form of sending a director to sit on the firm's board, is higher in Japan. The

\footnotetext{
${ }^{10}$ See Ramseyer (1987).

${ }^{11}$ For example, Aoki (1994) argues that the Japanese governance system enhances a firm's ability to use more efficient team-based methods of production in place of more hierarchical and specialized
} ("Western") methods of production. 
frequency of takeovers is higher in the U.S. Stakeholder monitoring substitutes to some extent for the non-existent market for corporate control in Japan.

Morck and Nakamura (forthcoming) examine the circumstances under which Japanese banks send directors to firms and conclude that bank monitoring is more focused on a firm's liquidity position than its profitability. They conclude that "bank oversight is an imperfect substitute for shareholder oversight." Kaplan $(1994,1997)$ found that turnover of the top managers of the largest Japanese firms was sensitive to the firm's stock price, earnings, and sales growth, and the sensitivities were similar in magnitude to those of the top managers of the largest U.S. firms. He also found that turnover of Japanese executives was more sensitive to poor earnings performance and less sensitive to stock returns than was turnover of U.S. executives. If earnings (rather than stock price) are the best indicator of a firm's ability to uphold its obligations to its customers, suppliers, and lenders, the second finding is consistent with the hypothesis that monitoring of Japanese executives is done primarily by (and in the interests of) stakeholders, not outside shareholders. ${ }^{12}$ These papers suggest that the monitoring activities of insider stakeholders are not aimed at forcing managers to pursue high returns for outside shareholders.

\section{How could the "Big Bang" change things?}

I have identified the problem facing Japan as a low return on wealth. Three reasons for these low returns are the lack of focus on maximizing shareholder returns, the relative weakness

\footnotetext{
${ }^{12}$ Kang and Shivdasani (1996) find that the stock price of Japanese companies goes up when top managers are forced out, and that large shareholders play a role when the new managers come from outside the firm. Kubo (1998) finds that Japanese managers' compensation (salary plus bonus) does not depend on shareholder return but does depend on employees' average wage and company profit.
} 
of institutional investors in Japan, and the absence of a market for corporate control. If the purpose of the "Big Bang" is to solve the problems facing Japan's financial system, the "Big Bang" should include measures to address these characteristics of the Japanese economy.

The current Japanese corporate governance system reflects the interaction of market forces and government policies over a period of decades. The relative importance of these two influences on the development of the Japanese corporate governance system is not clear-cut. Milhaupt (1996) argues that the Japanese legal system supports, but did not create, the Japanese corporate governance system. ${ }^{13}$ It may only be necessary for the "Big Bang" to remove legal and regulatory obstacles for change to occur.

\subsection{Focusing managers on shareholder returns}

\subsubsection{Equity-based compensation}

In a shareholder-oriented governance system, the incentives of corporate managers must be aligned with those of shareholders. One way this can be done is for part of managers' compensation to be linked to the firm's equity return, for example by shifting their compensation from cash to stock options. Event studies on U.S. firms show that a firm's market value rises by 2.4 percent on average when it introduces a stock option plan (Brickley, Bhagat and Lease 1985). Doubling the fraction of the CEO's pay that is equity-based is associated with a 4.3 percent increase in the firm's market value (Mehran 1995). Equity-based compensation is clearly good for shareholders.

\footnotetext{
${ }^{13}$ On the other hand, Weinstein (1997) argues that government policies have been the driving force. Kojima (1997, p. 125) argues that the shift of control away from shareholders was the result of deliberate government policy during World War II.
} 
A ban on stock option plans in Japan was lifted in June 1997; since then, about 70 large firms, representing about 5 percent of Tokyo Stock Exchange First Section firms, have adopted stock option programs. ${ }^{14}$ In contrast, 93 percent of a similar group of U.S. firms had stock option plans in 1996 (Peck 1998). In Japan, stock options obtained through corporate stock option plans are currently subject to unfavorable tax treatment, with only the first $¥ 10$ million of gains each year taxed at the low capital gains rate and the remainder taxed as ordinary income (at a higher rate). ${ }^{15}$ Although not a part of the "Big Bang," improving the tax treatment of stock options would make them more attractive to firms and make it easier to align managers' incentives with shareholders'.

\subsubsection{Independent boards of directors}

In a shareholder-oriented governance system, the board of directors is a key link between shareholders and managers. It is the responsibility of the board of directors to focus managers on maximizing shareholder value. A major trend in the U.S. in the past decade has been the reorientation of boards of directors toward shareholder interests. Boards that are too heavily populated by corporate insiders have come under fire from shareholders.

Empirical evidence on the effect of boards of directors in the U.S. suggests that more independent boards do a better job of monitoring managers at poorly-performing firms. Weisbach (1988) shows that the sensitivity of CEO resignation to a firm's stock market and accounting performance is higher at firms with outsider-dominated boards. However, studies looking for broader effects of board composition on return on equity typically find no effect (e.g.,

\footnotetext{
14"Japan's Ray of Hope," Financial Times, May 6, 1998.

15"New Tool in Tokyo," Wall Street Journal, April 9, 1998, p. R9.
} 
Bhagat and Black 1996). This suggests the positive effect of an independent board is limited to those firms where the need for monitoring is greatest. However, as I have argued, the need for monitoring to be done in the interests of shareholders is great in Japan, so the benefits of an independent board are also likely to be greater in Japan than in the U.S.

Japanese boards of directors have been criticized for being too closely tied to stakeholders. On average, only 22 percent of Japanese directors are not ex-employees, compared with 65 percent in the U.S., according to Fukao (1995, p. 14). Most represent insider shareholders, primarily banks (Kaplan and Minton 1994, Table 1B). In addition, Japanese boards are large, with a typical board having 20-25 members (Kojima 1997, p. 55), compared with 12 or 13 in the U.S. (Kaplan 1995). Their large size may inhibit their effectiveness. A prominent U.S. business group suggests that "smaller boards are often more cohesive and work more effectively than larger boards." (Business Roundtable 1997, p. 10).

One group calling for change is the Corporate Governance Forum of Japan (1998). Their "Corporate Governance Principles" call for Japanese boards to

- $\quad$ include a majority of independent, non-executive directors;

- be clearly separate from the executive board that is responsible for execution of business activities, and

- $\quad$ separate the positions of Chair of the Board and Chief Executive Officer.

These proposals resemble the "best practices" for boards of directors that have been promulgated in the U.S. in recent years. ${ }^{16}$ No laws prevent Japanese firms from making their boards more

\footnotetext{
${ }^{16}$ For example, the California Public Employees' Retirement System (CalPERS) has published "Corporate Governance Core Principles and Guidelines" focusing on the organization of the board of directors. Other groups that have published similar guidelines in the U.S. in recent years include the
} 
independent, and a handful of firms have done so. The "Big Bang" contains no measures to encourage more independent boards.

\subsubsection{Changes in firms' internal organization}

Another way to align managers' and shareholders' interests would be for Japanese firms to change their internal organization to enhance accountability. By moving away from an organization based on frequent personnel rotation throughout the firm toward one where managers identify with (and are identified with) an individual business unit, it would become easier to hold individual managers accountable for their performance. For example, a mid-sized Japanese brokerage firm has restructured itself into three units-trading, investment banking, and private banking-which will set their own salary and personnel systems. Its stated goal is to improve its return on equity before Big Bang deregulation is complete. ${ }^{17}$

The impediments to such change are largely organizational, not legal or regulatory. However, relaxation of the restrictions on holding companies in Japan would make it easier for firms to adopt sweeping organizational changes. While the ban on holding companies was removed in 1997, the lack of consolidated taxation in Japan and restrictions placed on the size of a holding company under the Anti-Monopoly Law limit the attractiveness of the holding company structure, limiting the beneficial effects that holding companies could have on improved accountability for corporate managers in Japan.

National Association of Corporate Directors and the Business Roundtable.

17"Kokusai to introduce in-house company system," Nikkei Weekly, April 6, 1998, p. 13. 


\subsubsection{Share buybacks}

A share buyback allows a manager to signal that future returns are likely to be high. It also lets a manager return capital to shareholders while avoiding the double taxation of dividends. Evidence on the U.S. shows that a firm's share price rises by 2.3 percent on average when an open market repurchase is announced. Moreover, the effect increases with the size of the announced buyback (Comment and Jarrell 1991).

Until 1995, share buybacks were prohibited in Japan. In light of the argument presented above that a weakness of the Japanese corporate governance system was its inability to monitor managers of cash-rich firms, this ban seems to have been unfortunate. Since the prohibition was lifted, more than 270 firms have announced buyback plans, representing 20 percent of Tokyo Stock Exchange First Section firms. ${ }^{18}$ Fenn and Liang (1998) report that, in an average year over 1984-95, 41 percent of a similar group of U.S. firms repurchased shares. The future tax treatment of share buybacks in Japan is uncertain, since the Ministry of Finance has given only a temporary waiver of taxation on share buybacks as implicit dividends. The "Big Bang" contains no provisions to encourage share buybacks.

\subsubsection{Shareholder lawsuits}

One action shareholders can take to influence corporate managers is to file a lawsuit against managers who allegedly cause damage to the company. Evidence in Strahan (1998) supports the idea that securities class action lawsuits help police U.S. managers. He shows that lawsuits are more common in firms more likely to need monitoring (e.g., large firms and nondividend paying firms) and that the probability of CEO turnover rises after a lawsuit is filed. In

\footnotetext{
18"Japan’s Ray of Hope," Financial Times, May 6, 1998.
} 
October 1993, Japan's Commercial Code was revised to reduce the fees required to file such a lawsuit. In the three months after the legal change, 84 derivative suits were filed. ${ }^{19}$ While facilitating derivative lawsuits gives shareholders another way to pursue redress against corporate mismanagement and may encourage managers to avoid grossly wasteful policies, it may be too much to hope for derivative lawsuits to implement the subtle change in managers' objectives from stakeholders' interests to shareholders' interests.

\subsection{Changes to institutional investors}

As discussed earlier, Japanese institutional investors are both small and passive. In contrast, institutional investors in the United States have taken an increasingly active role in corporate governance over the past decade, pressuring managers to improve shareholder returns. For example, the Council of Institutional Investors (CII) releases a list of poorly performing companies each year that it urges its members to target for governance-related improvements, such as increasing the number of outside directors and requiring directors to be paid in stock or stock options. ${ }^{20}$ Opler and Sokobin (1997) found that poorly-performing firms listed on the CII target list in 1991-94 outperformed other poorly performing firms and the market as a whole, consistent with the notion that pressure from institutional investors can affect corporate performance. Del Guercio and Hawkins (forthcoming) find that institutional shareholder pressure has an impact on the policies pursued at targeted firms. 1994, p. 1.

${ }^{19}$ "Shareholders turning to lawsuits to ensure executive accountability," Nikkei Weekly, May 9,

${ }^{20}$ Other large institutional investors, such as pension fund CalPERS, also release target lists of poorly-performing companies. 
On the other hand, many researchers who have studied the effect of institutional investors' pressure for changes to corporate governance on firm performance have found no effect. Black (1997, p. 3) surveyed this literature and concluded that "institutional investor activism doesn't importantly affect firm performance." It may not be surprising that the empirical literature to date has been inconclusive, because of the many problems these empirical tests face. For example, it is difficult to separate the effect of institutional investors' pressure from other factors affecting a firm's performance, because the decision to target a company is not exogenous. Moreover, most of the existing literature looks for an unconditional link between institutional investors' pressure for corporate governance reforms and firm performance. It may make more sense to look for a conditional link, for corporate governance to matter more at some times, e.g., when business conditions are bad and change is needed, than at others.

Growth of Japanese institutional investors could have additional positive effects on Japanese capital markets, even if they do not engage in active governance. A recent OECD study (Blommestein 1997) cited research showing that countries with a large institutional investor sector have more liquid and more efficient financial markets, more innovative risk-transfer strategies and more developed stock and bond markets. Simply by being large players, institutional investors that do not engage in active governance, such as mutual funds and corporate pension funds, can have a beneficial effect on financial market development, another area in which the "Big Bang" aims to have an effect.

Many aspects of the legal framework governing institutional investors in Japan have been changed or are already scheduled to be changed as part of the "Big Bang." Restrictions on the asset allocation of corporate pension funds were removed in 1997. Management of corporate 
pension funds is no longer restricted to trust banks and life insurance companies since 1997. Restrictions on investment in foreign mutual funds have largely been removed.

The response to these changes has already begun. Foreign mutual fund companies have begun to establish Japanese operations to sell investment trusts. For example, Fidelity opened an office in Tokyo in June 1997 to prepare for direct sales of investment trusts to individuals following deregulation. ${ }^{21}$ Japanese and foreign banks and securities firms have set up investment advisory firms to manage pension fund investments and the funds entrusted to these firms have been growing rapidly. ${ }^{22}$

Some legal changes have not yet been undertaken, but would be necessary to fully empower the institutional investor sector to contribute to a successful "Big Bang." I cite two examples. The current tax treatment of investment trusts is distortionary, because a seller's cost basis for tax purposes is set equal to the average acquisition cost of all investors in the trust, not to that seller's own acquisition cost. Cai, Chan and Yamada (1997) show that this distortionary tax treatment has contributed to severe underperformance of Japanese investment trusts. Reportedly, the relevant law will be changed in the 1998 fiscal year. Currently, when pension funds switch from one investment advisor to another, all investments must be liquidated and the funds reinvested by the new advisor. This raises the cost of switching advisors which limits competition for pension fund management. Reportedly, this requirement will be changed in the 1999 fiscal year.

\footnotetext{
${ }^{21}$ Nikkei Net News, December 5, 1997.

22"A giant sucking sound," The Economist, August 23, 1997, pp. 53-54.
} 
Again, some of the changes that are needed are not changes to laws, but changes to market practices. For example, until recently pension fund investment advisors have not been evaluated on the performance of the investments they select. Pension fund sponsors did not mark their portfolios to market, so they did not put much emphasis on investment performance. A Ministry of Finance advisory panel on accounting has recommended that mark-to-market accounting for corporate pension funds be introduced in the fiscal year beginning April 1, 2000. Comparative data on mutual fund performance is not widely available, as it is in some other countries. More pressure from households for institutional investors to provide higher returns is a necessary complement to the "Big Bang" reforms.

I have argued that institutional investors are more likely to contribute to improved corporate governance without requiring the development of an active market for corporate control. Given the mixed evidence from the U.S. on the ability of institutional investors to improve corporate performance through active monitoring of managers, it is possible that even a large Japanese institutional investor community would not be able to effectively pressure corporate managers to focus on shareholder value. In that case, developing a market for corporate control would be a necessary step to improve the returns on Japanese wealth. ${ }^{23}$

\subsection{Changes in the market for corporate control}

Hostile takeovers are rare in Japan. In the U.S., hostile takeovers function as a last-resort means of forcing change onto managers who cannot be persuaded by other means to maximize shareholder value. The near-absence of hostile takeovers in Japan reflects the key monitoring

\footnotetext{
${ }^{23}$ For the U.S., Black (1997, p. 3) argues that institutional investor activism "can't substitute for a vigorous corporate control market." Del Guercio and Hawkins (forthcoming) suggest that institutional investor activism may be effective because of its interaction with the hostile takeover market.
} 
role traditionally played by insider stakeholders and the passive role played by outside shareholders. According to Kester (1991, pp. 97-103), the legal impediments to an active market for corporate control in Japan appear to be no greater than in the U.S.

Given the lack of legal obstacles for the Big Bang to remove, it may be sufficient for the Big Bang to shift power to outside shareholders, and a market for corporate control will develop if needed. A decline in cross-shareholding would also seem to be a prerequisite to an active market for corporate control. It is worth noting, however, that use of hostile takeovers in the U.S. has declined in the 1990s as shareholders have used other means, such as enhancing the independence and authority of the board of directors, to focus managers' attention on increasing shareholder value. ${ }^{24}$

While hostile takeovers may be unlikely to flourish in Japan, a more limited market for corporate control in Japan may develop in the form of activist investors (wealthy individuals and specialized investment funds) who take minority stakes in poorly performing firms. Activist investors have been successful in the U.S. in pressuring managers to reverse inefficient diversification and increase return on equity, according to Bethel, Liebeskind and Opler (1998). Gorton and Kahl (1998) argue that activist investors are likely to face lower agency costs of pressuring managers of poorly performing firms to restructure, compared with professional asset managers. As a result, it is efficient for activist investors to acquire minority stakes in poorly performing firms and pressure managers to restructure. As discussed above, the rights of

\footnotetext{
${ }^{24}$ Another factor behind this trend is the increasing number of legal impediments that have been placed on hostile takeovers in the U.S.
} 
minority shareholders in Japan are not well-protected. The "Big Bang" contains no measures to enhance the power of minority shareholders.

\section{Conclusions}

The challenge facing the Japanese financial system is to help improve the allocation of resources to ensure that Japan's wealth earns a high return. "Big Bang" deregulation could push the Japanese financial system in the right direction by focusing on strengthening corporate governance. Changes such as stock option plans, independent directors, and share buybacks could help focus managers on shareholders' interests. Liberalizing the institutional investor sector could produce "active owners." Strengthening the rights of minority shareholders could lead to the creation of a partial market for corporate control. In some of these areas, laws could be changed. In other areas, laws are not an impediment to change, but habit and the self-interest of groups that would lose from deregulation may impede change. To date, only a minority of "Big Bang" reforms have been aimed at corporate governance, despite the fact that reforming corporate governance presents a promising opportunity for Japan to improve its future economic performance.

One can ask what might happen if the groups in Japan with no incentive for change-managers and bureaucrats-resist the pressure for change. Because restrictions on foreign investment have been eliminated, there is no reason why Japanese wealthholders should not place their wealth in investments that earn a risk-adjusted return commensurate with what is available in global markets. Absent changes in corporate governance that could pressure Japanese managers to increase earnings, a decline in Japanese stock prices could increase the 
expected return on Japanese stocks by reducing the valuation attached to an unchanged stream of corporate earnings. In either case, the risk-return tradeoff of Japanese equities would be made closer to that available in the global market. Barriers to foreign investment by Japanese households have been falling for several years in Japan, so it is possible that the poor performance of the Japanese stock market in the past few years is (at least partially) due to a convergence of Japanese stock market valuations with those available in global markets. 


\section{References}

Aoki, Masahiko (1994), "The contingent governance of teams: An analysis of institutional complementarity," International Economic Review 35:3 (August), 657-676.

Berglof, Erik and Enrico Perotti (1994), "The governance structure of the Japanese financial keiretsu,"Journal of Financial Economics 36:2 (October), 259-284.

Bethel, Jennifer E., Julia Porter Liebeskind, and Tim Opler (1998), "Block share purchases and corporate performance," Journal of Finance 53:2 (April), 605-634.

Bhagat, Sanjai and Bernard Black (1996), "Do independent directors matter?", working paper, March.

Black, Bernard S. (1997), "Shareholder activism and corporate governance in the United States," forthcoming in Peter Newman (Ed.), The New Palgrave Dictionary of Economics and the Law, Stockton Press.

Blommestein, Hans (1997), "The impact of institutional investors on OECD financial markets," Financial Market Trends 68 (November), 15-54.

Brickley, James A., Sanjai Bhagat, and Ronald C. Lease (1985), "The impact of longrange managerial compensation plans on shareholder wealth," Journal of Accounting and Economics 7:1-3 (April), 115-129.

Business Roundtable (1997), Statement on Corporate Governance (September).

Cai, J., K.C. Chan and T. Yamada (1997), "The performance of Japanese mutual funds," Review of Financial Studies 10:2 (Summer), 237-274.

Comment, Robert and Gregg A. Jarrell (1991), "The relative signaling power of Dutchauction and fixed-price self-tender offers and open-market share repurchases," Journal of Finance 46:4 (September), 1243-1271.

Corporate Governance Forum of Japan (1997), "Corporate governance principles - A Japanese view (Interim report)," working paper, October 30, 1997 (available at http://paperhost.ssrn.com/papers/9804/98041401.pdf).

Del Guercio, Diane and Jennifer Hawkins (forthcoming), "The motivation and impact of pension fund activism," forthcoming in Journal of Financial Economics. 
Fenn, George W. and Nellie Liang (1998), "Good news and bad news about share repurchases," Finance and Economics Discussion Series Working Paper 1998-4, Federal Reserve Board.

French, Kenneth R. and James M. Poterba (1991), "Were Japanese stock prices too high?", Journal of Financial Economics 29, 337-363.

Fukao, Mitsuhiro (1995), Financial Integration, Corporate Governance and the Performance of Multinational Companies, Washington, D.C.: The Brookings Institution.

Fukao, Mitsuhiro (1998), "Japanese financial instability and weaknesses in the corporate governance structure," Conference Paper 98-2-6, Keio University.

Gorton, Gary and Matthias Kahl (1998), "Rich investors, institutional investors, and dynamic corporate control," working paper, Wharton School (March).

Hanazaki, Masaharu and Akiyoshi Horiuchi (1998), "Why has Japan suffered from the serious bank crisis?", paper presented at the NBER Japan Project Meeting, April 17-18, 1998, Cambridge, Mass.

Hoshi, Takeo, Anil Kashyap, and David Scharfstein (1990), "The role of banks in reducing the costs of financial distress in Japan," Journal of Financial Economics 27:1 (September), 67-88.

Hoshi, Takeo, Anil Kashyap, and David Scharfstein (1991), "Corporate structure, liquidity, and investment: Evidence from Japanese industrial groups," Quarterly Journal of Economics 106:1 (February), 33-60.

Kang, Jun-Koo and Anil Shivdasani (1996), "Does the Japanese governance system enhance shareholder wealth? Evidence from the stock-price effects of top management turnover," Review of Financial Studies 9:4 (Winter), 1061-1095.

Kaplan, Steven N. (1994), "Top executive rewards and firm performance: A comparison of Japan and the U.S.", Journal of Political Economy 102:3 (June), 510-46.

Kaplan, Steven N. (1995), "The homogeneity of Japanese boards," Directors \& Boards 19:3 (Spring), 31-32.

Kaplan, Steven N. (1997), "Corporate governance and corporate performance: A comparison of Germany, Japan and the U.S.", in Donald H. Chew (Ed.), Studies in International Corporate Finance and Governance Systems (pp. 251-258), New York: Oxford University Press. 
Kaplan, Steven N. and Bernadette A. Minton (1994), "Appointments of outsiders to Japanese boards: Determinants and implications for managers," Journal of Financial Economics 36:2 (October), 225-258.

Kester, W. Carl (1991), Japanese takeovers: The global contest for corporate control, Boston: Harvard Business School Press.

Kojima, Kanju (1997), Japanese corporate governance: An international perspective, Kobe, Japan: Research Institute for Economics \& Business Administration, Kobe University.

Kubo, Katsuyuki (1998), "The determinants of executive compensation and its effect on company performance in Japan and in the UK," paper presented at the Workshop on Corporate Governance, Contracts, and Managerial Incentives, Berlin, July 2-4, 1998.

McCauley, Robert N. and Steven A. Zimmer (1989), "Explaining international differences in the cost of capital," Federal Reserve Bank of New York Quarterly Review, 14:2 (Summer), 7-28.

Mehran, Hamid (1995), "Executive compensation structure, ownership, and firm performance," Journal of Financial Economics 38:2, 163-184.

Milhaupt, Curtis J. (1996), "A relational theory of Japanese corporate governance: Contract, culture, and the rule of law," Harvard International Law Journal 37:1 (Winter), 3-64.

Morck, Randall and Masao Nakamura (forthcoming), "Banks and corporate control in Japan," forthcoming in Journal of Finance.

Morinaga, Teruki and Mitsuhiro Fukao (1997), "The current state of the Japanese corporate pension system and its problems," working paper, Keio University.

Nakatani, Iwao (1984), "The economic role of financial corporate grouping," in Masahiko Aoki, ed., The Economic Analysis of the Japanese Firm (pp. 227-58), New York: North Holland.

Okumura, Hiroshi (1989), "Stock cornering, takeovers, and tender offers: The economics of stock acquisitions", in Yukio Yanagida et al (Eds.), Law and Investment in Japan (p. 515), Cambridge, MA: East Asian Legal Studies Program, Harvard Law School.

Opler, Tim C. and Jonathan Sokobin (1997), "Does coordinated institutional shareholder activism work? An analysis of the activities of the Council of Institutional Investors," working paper, Ohio State University.

Peck, Charles (1998), Top Executive Compensation in 1996, New York: The Conference Board. 
Prowse, Stephen D. (1990), "Institutional investment patterns and corporate financial behavior in the United States and Japan," Journal of Financial Economics 27:1 (September), 43-66.

Prowse, Stephen D. (1992), "The structure of corporate ownership in Japan," Journal of Finance 47:3 (July), 1121-40.

Ramseyer, J. Mark (1987), "Takeovers in Japan: Opportunism, ideology, and corporate control," UCLA Law Review 35:1, 21-25.

Strahan, Philip E. (1998), "Securities class actions, corporate governance and managerial agency problems," working paper, Federal Reserve Bank of New York (June).

Weinstein, David E. (1997), "Foreign direct investment and keiretsu: Rethinking U.S. and Japanese policy," in Robert C. Feenstra (Ed.), The Effects of U.S. Trade Protection and Promotion Policies (pp. 81-116), Chicago: University of Chicago Press for NBER.

Weisbach, Michael S. (1988), "Outside directors and CEO turnover," Journal of Financial Economics 20:1-2, 431-460. 
Table 1. Deregulation timetable

Fiscal 1997

- Securities houses will be allowed to handle consumer payments for their clients

Fiscal 1998

- Companies and individuals can handle foreign-exchange transactions without government authorization

- Banks will be allowed to sell their own investment trusts over the counter

- Ban on financial holding companies will be lifted

- Firms can become securities brokerages without government licenses

- Securities houses will be allowed to expand asset management services

Fiscal 1999

Securities houses will be free to set their commissions on securities trading of any size

- Market-value method will be applied for marketable securities

- Barriers that restricted banks, trust banks and securities houses from entering each other's markets will be removed

Banks will be allowed to issue straight bonds

By the end of 2001

Banks, securities houses will be allowed to enter insurance sector

Schedule not set

- Enactment of a new financial services law that would govern banking, securities and insurance sectors

Source: Nikkei Weekly, June 16, 1997, p. 1. 
Table 2. Stock market return on equity in Japan and the U.S.

Panel A: $\quad$ Average stock market returns

(Continuously compounded annual stock return)

Japan U.S.

$\begin{array}{lll}1980-1998 * & 7.3 & 16.3\end{array}$

$\begin{array}{lll}1980-1994 & 9.8 & 13.5\end{array}$

Panel B: $\quad$ Average excess returns

(Continuously compounded annual stock return less continuously compounded annual return on risk-free asset)

Japan U.S.

1980-1998* $\quad 2.4 \quad 8.9$

$\begin{array}{lll}1980-1994 & 3.8 & 6.0\end{array}$

* Data for 1998 are through June

Notes: Stock market returns are calculated gross of dividends, before taxes, in local currency. The risk-free asset is invested at the 3-month Treasury bill rate for the U.S. and the Gensaki rate for Japan.

Source: MSCI, Federal Reserve Board, Bank of Japan. 
Table 3. Monitoring in Japan and the U.S.

\begin{tabular}{|c|c|c|}
\hline \multicolumn{3}{|c|}{$\begin{array}{l}\text { Frequency of External Monitoring } \\
\text { (percent per year, 1980-88 average) }\end{array}$} \\
\hline & Japan & U.S. \\
\hline $\begin{array}{l}\text { Appointment of a director } \\
\text { affiliated with a large shareholder }\end{array}$ & 13 & 2 \\
\hline Takeover & 0.3 & 2 \\
\hline \multicolumn{3}{|c|}{$\begin{array}{l}\text { Source: Kaplan and Minton (1994). Data cover the } 119 \text { largest industrial firms } \\
\text { in Japan and the } 146 \text { largest industrial firms in the U.S. }\end{array}$} \\
\hline
\end{tabular}


Table 4. Size of institutional investors in Japan and the U.S. (1994)

\begin{tabular}{|lcc|}
\hline & Japan & U.S. \\
Institutional investment assets/GDP & $85 \%$ & $142 \%$ \\
Household assets/GDP & $531 \%$ & $424 \%$ \\
Institutional investment assets/ & $16 \%$ & $33 \%$ \\
Household assets & & \\
Source: OECD, Federal Reserve Board, Bank of Japan. & & \\
\hline
\end{tabular}


Figure 1. Accounting return on equity in Japan and the U.S.

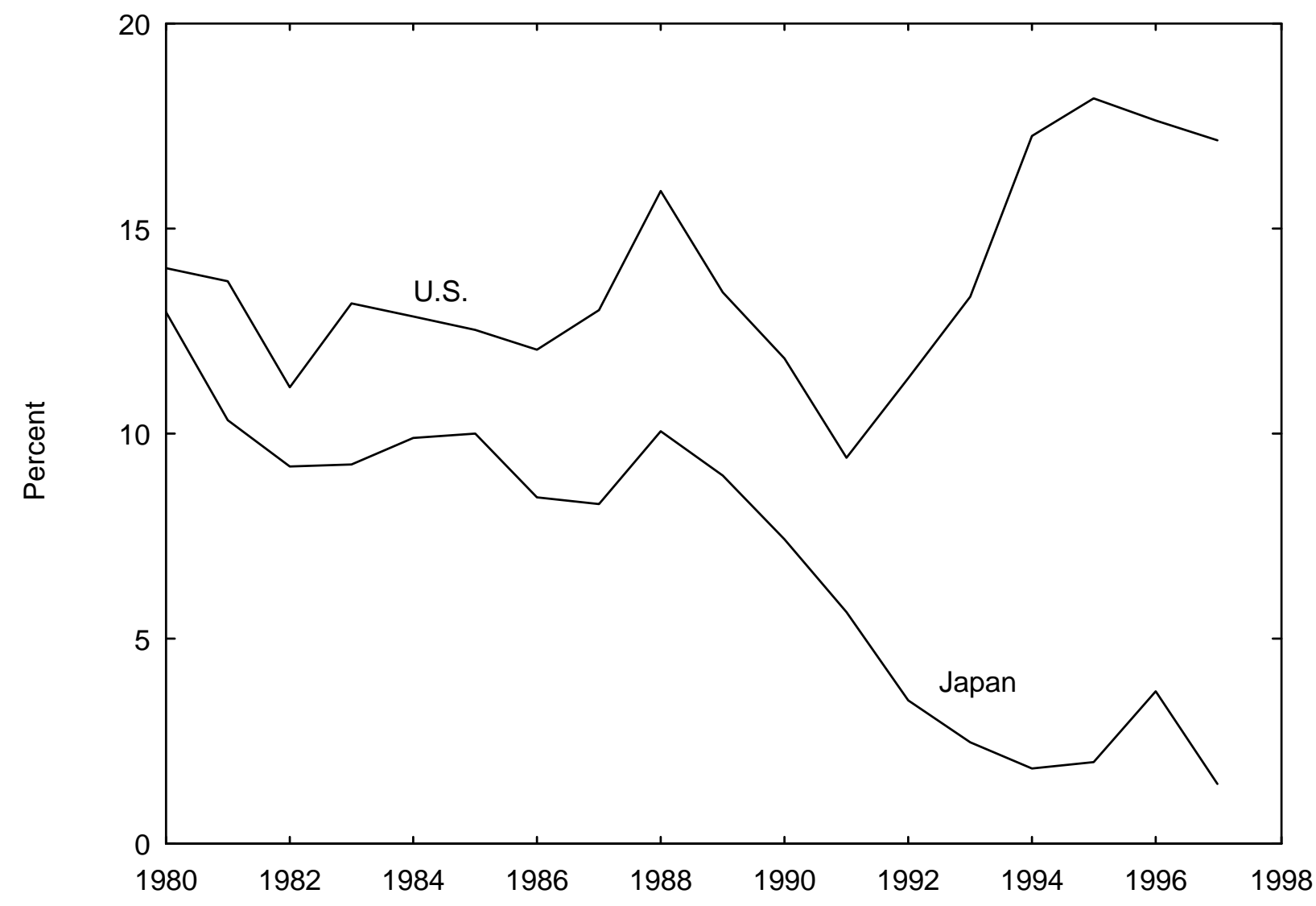

Notes: Accounting return is defined as earnings divided by book value. The accounting return for a given year uses the most recent fiscal year's data available in June of the following year (to capture data from Japanese fiscal years that end in March). The accounting return is actually computed as $(\mathrm{P} / \mathrm{BV}) /(\mathrm{P} / \mathrm{E})$, where both $\mathrm{P} / \mathrm{BV}$ and $\mathrm{P} / \mathrm{E}$ are taken from the MSCI database. 
Figure 2. Japanese stock market return

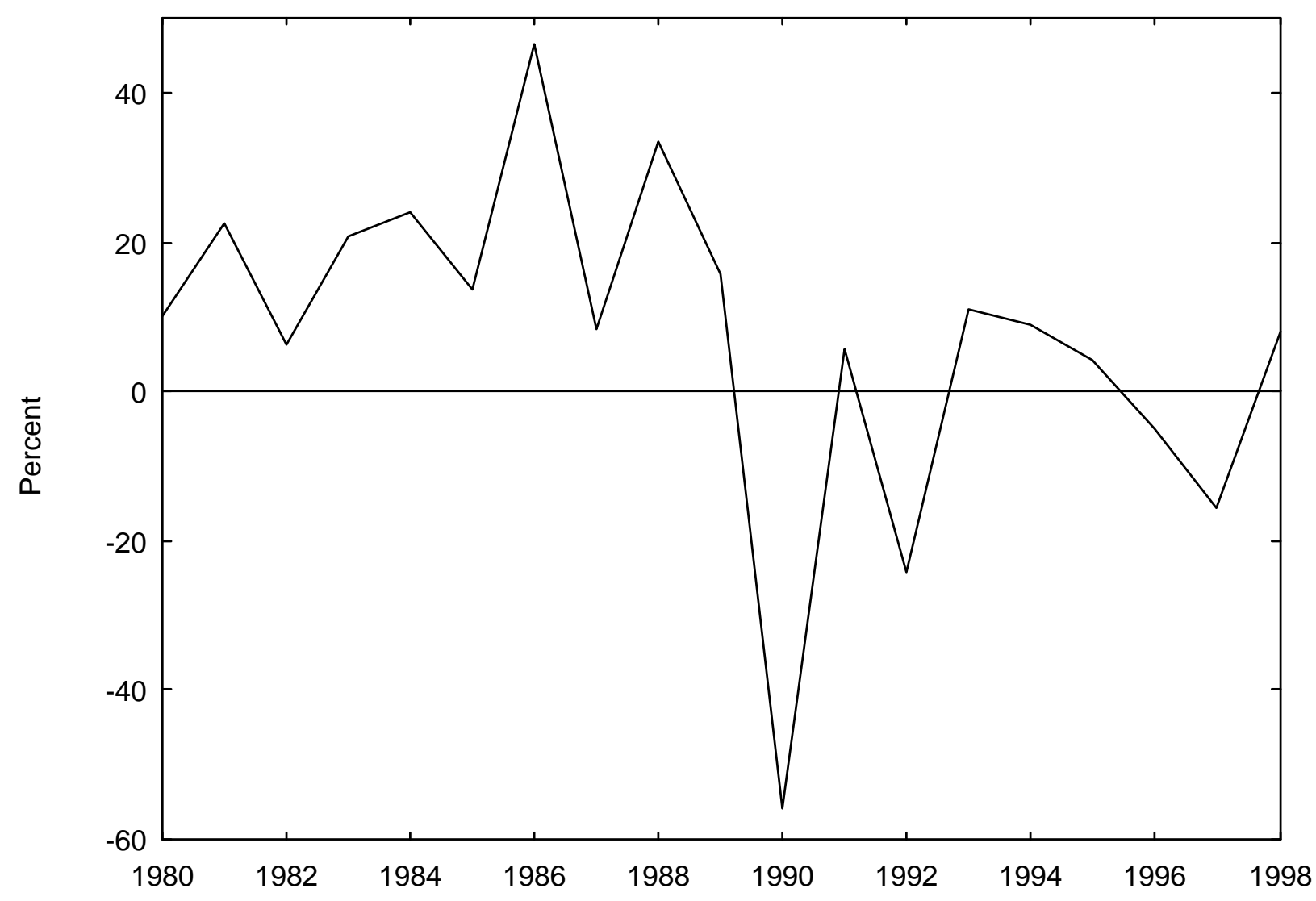

Note: Stock market returns are continuously compounded returns calculated gross of dividends, before taxes, in local currency. Data for 1998 are through June at an annual rate.

Source: MSCI. 